\title{
Proefschrift
}

\section{Problem-based learning as a preparation for professional practice}

Prince K (21 april 2006). Problem-based learning as a preparation for professional practice. Universiteit Maastricht. Promotoren: prof. dr. A.J.J.A. Scherpbier, prof. dr. C.P.M. van der Vleuten, prof. dr. H.P.A. Boshuizen. Maastricht: Universitaire Pers Maastricht; 2006. 160 pagina's. ISBN 905278-520-1. Voor meer informatie: k.prince@sk. unimaas.nl.

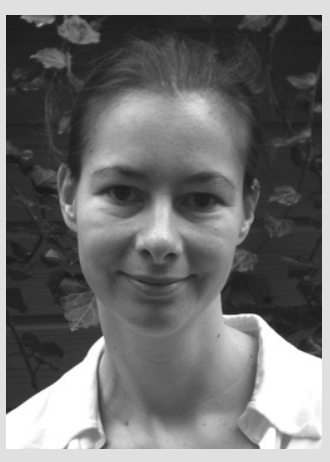

\section{Naam}

$1988-1996$

$1998-2004$

Huidige werkplek

\section{C.J.A.H. (Katinka) Prince}

Opleiding geneeskunde te Maastricht

AIOTHO Maastricht (gecombineerde aanstelling als huisarts in opleiding en promovenda op het gebied van medisch onderwijs)

Huisarts, Universitaire Huisartsenpraktijk VUmc, waarbij 1 dag per week werkzaam voor het Onderwijs Instituut (docentprofessionalisering medische vervolgopleidingen)
Probleemgestuurd onderwijs (PGO) is enkele decennia geleden ontwikkeld door een aantal idealistische docenten vanuit de onderwijspraktijk, zonder een echte duidelijke theoretische grondslag. De gedachte van de bedenkers van PGO was dat door het leren te koppelen aan de professionele context, de relevantie voor studenten duidelijker zou worden en de toepassing van de kennis in de praktijk zou verbeteren. De uiteindelijke verwachting was dat PGO studenten beter voorbereidt op de praktijk, maar dat is tot dusver niet bewezen. In het medisch opleidingscontinuüm (ten tijde van dit onderzoek) zijn twee overgangen aan te wijzen waarop theorie plaats maakt voor meer praktijk: de overgang van het preklinische, overwegend theoretische deel van de opleiding naar de coassistentschappen en de overgang van de ba- sisopleiding naar het werken als basisarts. De studies in dit proefschrift zijn gericht op de mening en ervaring van studenten en afgestudeerden over deze overgangen van theorie naar praktijk, waarbij speciaal wordt gekeken naar de rol van PGO zoals in de medische faculteit van Maastricht gehanteerd.

Studenten geneeskunde geven aan diverse problemen te ervaren bij de start van de coassistentschappen. Veel ervaringen komen voort uit professionele socialisatieprocessen, het aanpassen aan een nieuwe omgeving en werkdruk. Studenten geven aan onzeker te zijn, omdat niet duidelijk is wat van hen wordt verwacht. Ze voelen zich matig tot goed voorbereid wat betreft kennis en vinden hun vaardigheden om fysisch diagnostisch onderzoek uit te voeren voldoende. Studenten ervaren hiaten in 
hun kennis van de basisvakken, waarbij met name anatomie en farmacologie worden genoemd. Het toepassen van kennis in de praktijk wordt moeilijk gevonden, een opmerkelijk resultaat aangezien van PGO wordt verwacht dat het de toepassing van basisconcepten op echte klinische problemen vergemakkelijkt. Positieve ervaringen betreffen de patiënt contacten, die volgens de studenten zeer motiverend werken.

Suggesties voor verbetering van de overgang van het theoretische deel van de opleiding naar de coassistentschappen zijn vroege patiëntcontacten en meer hulp om bruikbare kennis te verwerven en te onthouden. Het toetssysteem moet overeenkomen met de doelstellingen van het onderwijs, omdat de examens het leren van studenten sterk beïnvloeden. Met andere woorden, indien de onderwijsorganisatie wil dat studenten leren kennis toe te passen op klinische problemen, dan moet dat ook in de toetsing tot uitdrukking komen. Verder adviseren studenten een uitgebreide introductie aan het begin van de coassistentschappen, een meer geleidelijke overgang met betrekking tot werkdruk en meer integratie van het preklinische en het klinische deel van de opleiding.

De geïntegreerde PGO-aanpak in Maastricht lijkt samen te gaan met onzekerheid en ervaren tekorten wat betreft basiskennis. Daarom werden in vervolgonderzoek de mening van studenten over hun kennis van de anatomie en de daadwerkelijke kennis van PGO- en niet-PGO-studenten vergeleken. Alle studenten blijken even onzeker over hun kennis. Alhoewel met behulp van een anatomietoets wel verschillen werden gemeten in de anatomiekennis van studenten van verschillende geneeskundeopleidingen, zijn er geen significante verschillen tussen de resultaten van de PGO-studenten en de niet-PGO-studenten. PGO leidt dus niet tot minder kennis van de anatomie in vergelijking met meer traditionele onderwijsmethoden. Om een uitspraak te kunnen doen over het algemene niveau van de anatomiekennis van studenten, is een absolute standaard nodig. Met behulp van een gemodificeerde Angoff-methode werd door vier groepen experts (anatomen, artsen, recent afgestudeerde basisartsen en vierdejaars geneeskundestudenten) een norm vastgesteld. Als de resultaten van de studenten op de anatomietoets worden vergeleken met de 'standaard' vastgesteld door vierdejaars studenten, dan zou $64 \%$ van de studenten zijn gezakt. De standaarden bepaald door de anatomen, clinici en afgestudeerden leiden tot respectievelijk 42\%, 58\% en $26 \%$ studenten die onvoldoende scoren. Volgens deze groepen beoordelaars weten veel studenten dus onvoldoende van anatomie. De hoge verwachtingen van de vierdejaars studenten (die tot uiting komen in de norm) hebben mogelijk bijgedragen aan de onzekerheid van deze groep over hun kennisniveau.

Voor de mening van afgestudeerden over de voorbereiding van de opleiding op de medische praktijk werd gebruik gemaakt van data van het Research Centrum voor Onderwijs en Arbeidsmarkt (ROA) in Maastricht over een PGOfaculteit en vier niet PGO-faculteiten. De PGOafgestudeerden beoordelen de overgang van opleiding naar werk en de voorbereiding op de praktijk beter dan hun collegae. In het algemeen lijken de afgestudeerden tevreden over hun kennis en vaardigheden. Alle afgestudeerden geven aan dat van de competenties die ze in de praktijk gebruiken met name de competenties 'domein gerelateerde kennis', 'vakspecifieke vaardigheden' en 'communicatievaardigheden' voldoende tijdens de opleiding aan bod zijn gekomen. Meer PGO- dan niet-PGO-afgestudeerden geven aan dat communicatievaardigheden voldoende aan bod zijn gekomen. Alle afgestudeerden geven aan dat het nodig is meer aandacht in het curriculum te besteden aan andere competenties, zoals het werken met computers, plannen en organiseren en leidinggevende vaardigheden. Aanvullend kwalitatief onderzoek onder de afgestudeerden uit Maastricht toont dat de overgang van student naar arts als groot wordt beschouwd, met name door de toegenomen verantwoordelijkheid, de toegenomen werkdruk en de verandering in de omgang met andere zorgverleners en patiën- 
ten. De problemen die worden gesignaleerd zijn gerelateerd aan onvoldoende kennis en vaardigheden met betrekking tot praktische procedures. De overgang kan worden vergemakkelijkt door eerder in de opleiding meer patiëntcontacten in te voeren, studenten meer te betrekken bij het medisch vervolgbeleid en coassistenten geleidelijk meer verantwoordelijkheid te geven.

Samengevat zijn de belangrijkste conclusies van dit proefschrift als volgt. Veel van de problemen die studenten ervaren bij de aanvang van de coassistentschappen kunnen worden toegeschreven aan professionele socialisatie. Alhoewel PGO de toepassing van kennis bij klinische problemen zou moeten stimuleren, hebben studenten moeite met het toepassen van hun kennis in de praktijk. PGO-studenten zijn even zeker (of onzeker) over hun kennis van anatomie als hun collega's en hebben ook vergelijkbare kennisniveaus. De overgang van de geneeskundeopleiding naar het werken als basisarts wordt eveneens gezien als grote overgang, met name door de toegenomen verantwoordelijkheid en werkdruk. PGO lijkt de studenten te helpen bij de voorbereiding op de praktijk door het stimuleren van algemene vaardigheden. Als suggesties voor verbetering worden genoemd het aanpassen van het toetssysteem aan de onderwijsdoelen, meer patiëntcontacten en het toepassen van kennis vroeg in de opleiding. Een verdere verbetering van de overgang van theorie naar praktijk kan worden bereikt door een meer geleidelijke toename van de verantwoordelijkheid van studenten voor zowel het eigen leren als de zorg voor patiënten. 